\title{
Article
}

\section{Private Revenge and its Relation to Punishment}

\author{
Rosebury, Brian
}

Available at http://clok.uclan.ac.uk/3395/

Rosebury, Brian ORCID: 0000-0002-6154-2685 (2009) Private Revenge and its Relation to Punishment. Utilitas, 21 (01). pp. 1-21. ISSN 0953-8208

It is advisable to refer to the publisher's version if you intend to cite from the work. http://dx.doi.org/10.1017/S0953820808003336

For more information about UCLan's research in this area go to http://www.uclan.ac.uk/researchgroups/ and search for <name of research Group>.

For information about Research generally at UCLan please go to http://www.uclan.ac.uk/research/

All outputs in CLoK are protected by Intellectual Property Rights law, including Copyright law. Copyright, IPR and Moral Rights for the works on this site are retained by the individual authors and/or other copyright owners. Terms and conditions for use of this material are defined in the policies page.

\section{CLoK}

Central Lancashire online Knowledge www.clok.uclan.ac.uk

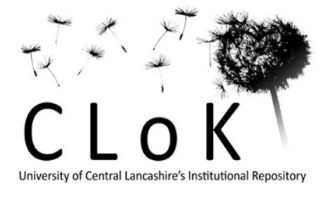




\title{
Private Revenge and its Relation to Punishment
}

\author{
BRIAN ROSEBURY \\ University of Central Lancashire
}

In contrast to the vast literature on retributive theories of punishment, discussions of private revenge are rare in moral philosophy. This article reviews some examples, from both classical and recent writers, finding uncertainty and equivocation over the ethical significance of acts of revenge, and in particular over their possible resemblances, in motive, purpose or justification, to acts of lawful punishment. A key problem for the coherence of our ethical conception of revenge is the consideration that certain acts of revenge may be just (at least in the minimal sense that the victim of revenge has no grounds for complaint against the revenger) and yet be generally agreed to be morally wrong. The challenge of explaining adequately why private revenge is morally wrong poses particular difficulty for purely retributive theories of punishment, since without invoking consequentialist reasons it does not seem possible adequately to motivate an objection to just and proportionate acts of revenge.

'Revenge' is a familiar term in ordinary discourse, and is often deployed polemically in public debate. But we will be disappointed, or at least confused, if we look to the philosophical literature to clarify our thoughts about it. Many philosophers who refer to revenge give the impression of having one eye on some more elevated topic; and the philosophical literature lacks the continuity, the sense of an ongoing debate around consistent or emergent issues, to be found in many other areas of moral philosophy.

There are, I believe, two main reasons for this. One is the evident impossibility of erecting a firewall between the discussion of private revenge ${ }^{1}$ and the discussion of legal punishment, the lawful affliction of convicted wrongdoers by the criminal justice system. Indeed, in most writers, any discussion of the vengeful motives or actions of private individuals is as a strategic prelude or annex to a theory of punishment. There is enough resemblance between the two practices to suggest certain questions to any reflective person. Is punishment in a wellordered society to be understood as a legally authorized and controlled form of revenge? Is it a justifying purpose of legal punishment that it removes the need for, or diminishes the temptation to, private revenge? What, if anything, connects the vindictive feelings of the person injured

${ }^{1}$ By 'private' I mean simply 'without legal authority'. I do not mean to limit the expression to acts performed without public knowledge or outside the public arena.

(C) 2009 Cambridge University Press

doi:10.1017/S0953820808003336
Utilitas Vol. 21, No. 1, March 2009

Printed in the United Kingdom 
by a crime, the sympathetic indignation of the observing public, and the judgements, beliefs and objectives that motivate our criminal justice system in punishing the offender? These are recurring and still unresolved questions: not only is there no consensus on the answers but in one or two cases, as we shall see later, individual philosophers have equivocated or admitted their own uncertainty. Instead of a firewall between the topics of revenge and punishment, we have an irregular hedge in poor repair.

There is a second and even more basic reason for the incoherence in the existing literature on revenge. This is that the philosophers who have considered the subject have not been able to agree on the conditions which make the term 'revenge' applicable to an action. The common ground necessary for productive debate is lacking. There is, to be sure, a perceptible common tendency towards limiting the definition of revenge, in such a way as to dissociate it from it other, more generally esteemed practices (such as punishment, or manifestations of righteous anger) which may seem to resemble it. But the limitations vary a good deal. Some philosophers restrict the application of the term 'revenge' to cases of disproportionate retaliation. Some restrict it to acts carried out 'in cold blood'. Some restrict it to retaliation which is - or alternatively, is not - grounded in moral indignation, or which is grounded in an affronted sense of honour, or which is necessarily 'malicious' in its motivation. ${ }^{2}$ In many cases the limitation of the definition serves a clear strategic purpose in some larger argument.

Among recent writers, for example, Charles K. B. Barton, defending revenge, insists that it logically requires a judgement of moral wrong: for Barton, 'revenge is a form of punishment', and anyone who seeks revenge without appealing to the kinds of moral justification associated with punishment is at best 'confused' or imperfectly socialized. ${ }^{3}$ Suzanne Uniacke, aiming, in contrast, to explain why revenge is wrong, defines it as 'payback for an injury qua injury' and as 'typically malicious'; Uniacke reserves the term 'vengeance' for retaliation which appeals to moral judgement on an offence. ${ }^{4}$ The disagreement here is as much terminological as substantive, but it is striking that 'revenge', a common English expression, can be used simultaneously by two capable philosophers in mutually exclusive, yet equally restrictive, senses.

${ }^{2}$ See S. Uniacke, 'Why is Revenge Wrong?', Journal of Value Inquiry 34 (2000), pp. 619; J. Elster, 'Norms of Revenge', Ethics 101 (1990), pp. 862-85; G. Wallace, 'Wild Justice', Philosophy 70 (1995), pp. 363-75. For Wallace, cf. n. 46.

${ }_{3}$ Charles F. B. Barton, Getting Even: Revenge as a Form of Justice (Chicago and La Salle, 1999), pp. 25-6, 78-82; cf. J. Kleinig, Punishment and Desert (The Hague, 1973), p. 39.

${ }^{4}$ Uniacke, 'Why is Revenge Wrong?', pp. 61-9. 
Even Robert Nozick, in an otherwise convincing account of differences between retribution and revenge, is surely wrong to claim that, as a matter of definition, 'revenge involves a particular emotional tone, pleasure in the suffering of another'. ${ }^{5}$ While this emotional character may sometimes be present, counter-examples can be imagined, and they provide some of the most interesting cases. A revenger - for example, a person whose child has been murdered - may aim simply to end her victim's intolerably continuing existence, and may feel no pleasure in the act of doing so; and if suffering is inflicted in the process, she may derive no pleasure whatever from contemplating it. The motive in such a case may be to carry out what for her is a psychologically necessary act, to allay her own pain by acting in perceived vindication of a loved one, against an afflictor to whose actual feelings she is indifferent. To ignore this kind of possibility, to identify acts of revenge with acts motivated by spite (that is, vindictive pleasure in another's suffering) is subtly to prejudge the case against it.

Quite apart from the fact that the restrictions mentioned above disproportionateness, cold-bloodedness, maliciousness, moral disapproval, absence of moral disapproval, etc. - sometimes contradict one another, their restrictiveness itself seems premature. It is true that revenge, as Jacobean tragedy shows, can be accompanied by turbulent emotions and excessively drastic or malicious actions, but in ordinary discourse a pedantically proportionate 'Tit-for-Tat' would count as revenge (as in - lowering the cultural tone a little - the Laurel and Hardy film with this title, in which two shopkeepers take turns to damage one another's goods and premises). It seems more convenient to apply the term 'revenge' to both types of case, and to distinguish when necessary between proportionate and excessive revenge. Similarly, we may distinguish, if we need to, between revenge motivated by an act which the revenger both resents and judges to be morally unjustified, and an act which she merely resents as harming or afflicting her, irrespective of any moral judgement. As to any supposed requirement of cold-bloodedness, common observation shows that a wide range of emotional states, from icy calm to frenzied rage, are consistent with the committing of private vengeful acts. The popular saying that 'revenge is a dish best eaten cold' tends to confirm this view since, while it advocates calmly planned vengeance, its implication is that there is a need to advise potential revengers against the hot and hasty alternative.

${ }^{5}$ R. Nozick, Philosophical Explanations (Oxford, 1981), p. 367. 
Let us therefore work with a definition of revenge which accommodates all the variants noted above.

An act of revenge is any deliberate injurious act against another person which is motivated by resentment of an injurious act or acts performed by that other person against the revenger, or against some other person or persons whose injury the revenger resents.

Unless the context indicates otherwise, this should be taken as the background definition throughout the following discussion. 'Injury' should be taken in its widest possible sense, to include psychological distress. 'Acts' are assumed to be intentional; it is further assumed that the revenger has reasonably ascribed the original injurious acts to the victim of her revenge. (Consequently, afflicting acts against persons one knows, or ought to know, to be innocent of injurious intent are excluded from the definition. $)^{6}$

The main aim of the article will be to demonstrate that our collective understanding of revenge (as displayed by the classical and modern philosophical texts, and by popular or 'common-sense' arguments, surveyed in section II) is incoherent, and that this incoherence suggests the presence of unresolved tensions in our moral thought: in particular, a tension between morality and justice. It will exemplify and underline this last point in section III by demonstrating that the challenge of explaining adequately why private revenge is morally wrong poses particular difficulty for certain purely retributive (i.e. justice-driven) theories of punishment. These are limited aims, and I will note at the end, in section IV, some of the directions in which further investigation might be pursued.

More than a hundred years ago, T. H. Green remarked that the public discourse about punishment 'borrows the language of private revenge, just as the love of God borrows the language of sensuous

\footnotetext{
${ }^{6}$ The definition thus excludes various marginal uses of 'revenge' in ordinary discourse. The most common is these is to denote harm inflicted on unoffending but associated third parties. For example, 'area bombing' of German civilian targets by the British during the Second World War has sometimes been attributed partly to 'revenge' for the bombing of British cities by the Luftwaffe, yet the inhabitants of Hamburg, Dresden, etc. did not (with rare exceptions) participate in the Luftwaffe's strikes, or in any true sense authorize them. On the definition in the text, such examples would lie outside revenge; or to the extent that they may have been motivated by a confused identification of their victims with those who did authorize the bombing of Britain, they could be described as 'misdirected revenge'. It does not really matter for present purposes, since this article will focus on appropriately directed acts of revenge.
} 
affection'. ${ }^{7}$ The implication of Green's analogy is that the borrowing is a mere metaphor, but the transfer of terminology from one field to another often tends to drag some conceptual baggage with it, or to reflect some prior perception of similarity between the two fields. We need to consider in reviewing the literature whether, in this case, the borrowing is innocently metaphorical, reflects some actual equivalence or resemblance between private revenge and public punishment, or is a sign of confusion which needs to be disentangled.

An immediate problem for such an inquiry is that private acts of revenge, their reasons and their motives, their ethical status, are seldom discussed by philosophers. What typically happens is that discussions of the moral psychology of resentment, a phenomenon assumed to be readily understood, are attached to, or deviate immediately into, discussions of the explanation and justification of legal punishment, a matter generally agreed to be problematic. Philosophers often acknowledge the influence of vengeful emotions on the public discourse about crime and punishment, but there is little consensus as to whether the existence of these emotions should be regarded as an indispensable support to criminal justice, or as an embarrassment to it. Some writers firmly differentiate both the motives and the aims of punishment from those of revenge, while for others, either the motives or the aims of punishment, or both, necessarily resemble those of revenge.

A rare example of a philosopher who does directly discuss private revenge, rather than annexing it to the discussion of punishment, is Aristotle. In Book IV of the Nicomachean Ethics he asserts that to feel and express proportionate anger at injuries and insults is right, and recognizes the possibility that unexpressed resentment will fester and cause more harm in the end than immediate wrath: part of this harm being the need to seek relief by active retaliation. $\mathrm{He}$ finds the excess of anger to be the more common departure from the mean. ${ }^{8}$ Aristotle does not indicate in this passage when, if ever, private retaliatory acts motivated by proportionate anger (as distinct from mere feelings or expressions of anger) are compatible with virtue. In a later passage, however, he observes that people 'expect to return evil for evil - and if they cannot, feel that they have lost their liberty or good for good'; and he associates this expectation with the socially bonding reciprocity of economic exchange and mutual benefaction. But he rejects the lex talionis (in a form he attributes to the Pythagoreans)

7 T. H. Green, 'Principles of Political Obligation', Works of Thomas Hill Green, vol. 2, ed. R. L. Nettleship (London, 1893), p. 490.

8 Aristotle, Nicomachean Ethics, trans. J. A. K. Thomson and H. Tredennick (Harmondsworth, 1976), IV, v (1126a), pp. 161-2. 
and sketches a theory of legal penalties which reflects the influence of non-retributive purposes such as the maintenance of respect for officials. ${ }^{9}$ His other references to punishment in the Nicomachean Ethics also lay emphasis on its reformative and socially educative functions. ${ }^{10}$

Kant, in contrast, argues in The Metaphysical Elements of Justice that the lex talionis, derived from the 'principle of equality' (which here requires, in brief, that the harm you do to others you must find that you have done to yourself) is the compulsory standard of lawful punishment - to the point of insisting, notoriously, that a community about to disband itself must first take care to execute the last murderer in its prisons 'so that everyone will duly receive what his actions are worth'. Kant is careful, however, to observe that the required severity of each punishment under the law of retribution must be determined in a court of justice 'and not in your private judgement'. ${ }^{11}$ The implication, as we should expect from Kant, is that retaliation is to be guided by dispassionate rational judgement and cleared of any association with the psychology of vengeance. Hegel's view is much the same (though I shall revisit an aspect of it later). ${ }^{12}$

In an earlier discussion Kant appears to construe revenge as the excess of the legitimate defence of one's rights against a person who infringes them, or as the outcome of emotions which tend to drive us beyond the reasonable assertion of rights. 'We become implacable and think only of the damage and pain which we wish to the man who has harmed us. ${ }^{13}$ The example Kant chooses of a proper assertion of right insisting on being paid the agreed fee for one's work - makes vengeful excess look like mere peevishness. What would count as excess, in Kant's view, in the case of a response to really serious injury such as the murder of a close relative, and what would count in such a case as a proper and indeed obligatory assertion of a right, is hard to say, unless the answer is simply that the redress of such serious wrongs must pass from the wronged individual to the criminal justice authorities. But by setting up the norm in the rational and institutional form of a right, Kant in any case effectively dismisses the psychology of personal resentment as mere 'noises off'.

\footnotetext{
9 Aristotle, Nicomachean Ethics, V, v (1132b-1133a), pp. 182-4.

10 Aristotle, Nicomachean Ethics, II, iii (1104b), p. 95; III, v (1113b), p. 123; X, ix (1180a), p. 337.

11 I. Kant, The Metaphysical Elements of Justice, trans. J. Ladd (Indianapolis, 1983), pp. $100-2$.

12 G. W. F. Hegel, Philosophy of Right, trans. T. M. Knox (Oxford, 1967), ss. 102, 220: pp. $73,141$.

${ }^{13}$ I. Kant, 'Vengeance', Lectures on Ethics, trans. L. Infield (London, 1930), p. 214.
} 
Aristotle and Kant are thus at one, though for widely different reasons, in discountenancing the idea that punishment is legalized revenge, the former because he adopts what might be called a utilitarian or consequentialist view of punishment, oriented towards education rather than retribution, the latter because he firmly dissociates the duty of retributive punishment from the satisfaction of vengeful feelings.

Hobbes in his brief account of 'revengefulness' in The Elements of Law asserts that its aim is to make our adversary acknowledge that his action to hurt us has proved hurtful to himself. Though this resembles the principle that for Kant is the foundation of legal retributive justice, Hobbes attaches a literal psychological meaning to what for Kant is essentially a formal requirement: thus revenge, according to Hobbes, cannot aim at our adversary's death, since dead men cannot literally 'acknowledge' anything. ${ }^{14}$ In Leviathan, Hobbes is careful to emphasize that 'the aym of [legal] Punishment is not a revenge, but terrour'; ${ }^{15}$ underlying this claim is the proto-utilitarian argument, encapsulated in the seventh of Hobbes's laws of nature, that self-interest requires us to look to future good, not to act through resentment of past evil: 'Revenge without respect to the Example, and profit to come, is a triumph, or glorying in the hurt of another, tending to no end; (for the End is always somewhat to come). ${ }^{16}$ Locke's confessedly 'strange doctrine' that every man has a right to punish an offender 'but only to retribute to him, so far as calm reason and conscience dictates, what is proportionate to his transgression' 17 also invokes an impersonal law of nature, and the insistence on 'calm reason and conscience' suggests that Locke does not have personally motivated revenge in mind: the punisher serves the Law, not his own relief of mind. Neither Hobbes nor Locke quite seems to fit T. H. Green's general claim that seventeenthand eighteenth-century philosophers construed the state's right to punish as derived from the individual's right to 'self-vindication' indeed Hobbes explicitly rejects this idea. ${ }^{18}$ Green himself emphasizes that it is not true that in legal punishment as it should be there survives any element of private vengeance'. ${ }^{19}$ Green recognizes the role of public anger in motivating support for legal punishment, but

14 T. Hobbes, The Elements of Law, ed. J. C. A. Gaskin (Harmondsworth, 1994), ch. IX, p. 52 .

15 T. Hobbes, Leviathan, ed. R. Tuck (Cambridge, 1996), ch. XXVIII, pp. 215-16.

${ }^{16}$ Hobbes, Leviathan, ch. XV, p. 106.

17 J. Locke, Second Treatise of Government, ed. P. Laslett (New York, 1963), ss. 8-9, pp. 312-13.

18 Hobbes, Leviathan, ch. XXVIII, p. 214.

19 Green, 'Principles of Political Obligation', p. 487. 
holds that this disinterested indignation at crime is quite different from personal vengefulness. ${ }^{20}$

Joseph Butler in his sermons on 'Resentment' and 'Forgiveness of Injuries' similarly acknowledges the necessity of indignation against wickedness in motivating the detection and punishment of offenders, but in contrast to Green he sees it as differing only in degree, not in kind, from personally motivated resentment, and indeed as being essentially the same passion, 'a fellow feeling, which each person has in behalf of the whole species, as well as of himself'. ${ }^{21}$ The proposition that 'resentment' has been implanted in the human heart by God as a strategy to counteract wickedness allows Butler to equivocate a little over its moral status, characterizing it at one point as 'not only innocent, but a generous movement of mind' 22 while at another he regrets that action against offenders could not be motivated by 'a better principle, reason and cool reflection'. ${ }^{23}$ Though Butler carefully differentiates 'resentment' from 'the dreadful vices of malice or revenge', he notes that the one can tempt us to 'run into' the other, implying the view that it is the discharge of excessive resentment that counts as revenge. ${ }^{24}$ The social utility of resentment is negated if it is not 'subservient to... the Common Good': unconstrained, it leads to 'endless rage and confusion' ${ }^{25}$

Bentham's position is apparently more straightforward. His unqualified identification of pleasure with good entails that the 'dissocial' pleasure of gratifying ill-will 'is as good as any other that is not more intense'; the 'vindictive satisfaction' of the injured party at the punishment of an offender ranks as a 'collateral end' of punishment. If Bentham in practice allows no justification for private revenge, it is because the pleasure it accords to the revenger is (according to him) inevitably less than the pain suffered by the person afflicted; since this is true of legal punishment, which requires other justifying contributions to utility to compensate for this deficit, it is true a fortiori of private retribution, where resentment operates unregulated by the principle of utility. ${ }^{26}$ Nevertheless, as Bentham is aware, from the point of view of the revenger, the motive of seeking satisfaction is the same

${ }^{20}$ Green, 'Principles of Political Obligation', pp. 486-511, esp. 487-9.

21 J. Butler, 'Upon Resentment', Butler's Sermons, ed. W. R. Matthews (London, 1914), p. 126.

${ }^{22}$ Butler, 'Upon Resentment', p. 132.

${ }^{23}$ Butler, 'Upon Resentment', p. 131.

${ }^{24}$ Butler, 'Upon Resentment', p. 132.

25 J. Butler, 'Upon Forgiveness of Injuries', Butler's Sermons, ed. W. R. Matthews (London, 1914), p. 133.

${ }_{26}$ J. Bentham, Principles of Morals and Legislation, ed. J. H. Burns and H. L. A. Hart (London, 1982), X, p. 10 \&n, p. 100; X, pp. 34, 116; XIII, p. 2 \&n, pp. 158-9; II, pp. 19, $32-3$. 
whether a legal or extra-legal route to the affliction of the offender is taken. ${ }^{27}$

John Stuart Mill attempts to reconcile the positive and negative views of resentment: 'the natural feeling of retaliation or vengeance... has nothing moral in it; what is moral is, the exclusive subordination of it to the social sympathies'. The natural feeling resents 'whatever any one does that is disagreeable to us'; just persons, in contrast, resent only 'in the directions conformable to the general good'. ${ }^{28}$ But this formulation leaves us wondering what role is played by the emotion of resentment that is not already occupied by rational judgements of utility, and reflecting that a person capable of such firm 'subordination' can hardly be said to be experiencing resentment at all. Moreover, the scope attributed by Mill to the natural feeling of vengeance is surely too wide: we feel vengeful not about any disagreeable act, but about those we believe have injured us, and once this is granted, the possibility of a justified vengefulness that is quite indifferent to the common good is harder to exclude.

Sidgwick is more frankly ambivalent. He notes the Common Sense view that 'resentment for wrong' is 'legitimate and proper', and the failure of Common Sense, on the other hand, to have a clear view on what actions might be permissible where government fails to inflict a punishment commensurate with the injury felt by the victim. Common Sense concludes that while malevolent feelings ought in general to be condemned, it may be necessary to relax this condemnation in respect of the gratification of resentment against criminals, 'only it is not clear as to the limits or principles of this relaxation'. ${ }^{29}$ Sidgwick's strategy of using Utilitarianism to correct the deficiencies of Common Sense offers only limited help. If indignation aroused by crimes could be directed

always against acts, and not against persons...this would seem to be the state of mind most conducive to the general happiness. But it is doubtful whether average human nature is capable of maintaining this distinction, and whether, if it could be maintained, the more refined aversion would by itself be sufficiently efficacious. ${ }^{30}$

Even advocates of the view that punishment should give effect to the vengeful sentiments of the public, such as Fitzjames Stephen, generally stop short of countenancing private revenge. Stephen couples vengeance with sexual desire, as legitimate passions 'peculiarly liable to abuse': he writes in Aristotelian terms of its susceptibility to excess

${ }^{27}$ Bentham, Principles of Morals and Legislation, X, pp. 26, 111-12.

28 J. S. Mill, 'Utilitarianism', ch. 5, Utilitarianism, ed. M. Warnock (London, 1965), p. 307.

${ }_{29}$ H. Sidgwick, The Methods of Ethics, 7th edn. (London 1967), III, VII, 1, pp. 321-4.

${ }^{30}$ Sidgwick, The Methods of Ethics, IV, III, 5, p. 449. 
and deficiency (the latter appearing to him the greater danger for his contemporaries), and he adds that 'the forms in which deliberate anger and righteous disapprobation are expressed, and the execution of criminal justice is the most emphatic of such forms, stand to the one set of passions in the same relation in which marriage stands to the other'. ${ }^{31}$ On this view (though Stephen does not say so) an act of private revenge would presumably be morally reprehensible in rather the same way as an extra-marital affair. A not dissimilar view is that of Roger Scruton, for whom punishment 'removes the necessity for private revenge'; the failure of liberal societies to satisfy the 'common man's' conception of punishment as institutionalized revenge 'fosters the desire for personal, rather than institutional revenge' - presumably, even in Scruton's view, a desire we should avoid fostering. ${ }^{32}$

For a wholehearted assimilation of revenge to punishment in the classical literature, we have to turn to a sociologist. Durkheim ascribes the origin of punishment to an emotional reflex of vengeance, often disproportionate in its vehemence to the injury suffered by the revenger. Legal punishment transcends private revenge in redefining its target as the outrage against collective morality, the deepest values of the punishing community, rather than against the individual, and in more carefully graduating the retaliatory act to the seriousness of the offence; but the vengeful motive for punishment is still visible in the emotional appeals that accompany the deliberations of the law courts, and in the opprobrium visited on the offender over and above his material punishment. Others, such as Nietzsche and Freud, have discerned in the exercise of legal punishment not only a residue of vengefulness but also an outlet for repressed sadism. ${ }^{33}$

A rare example of a contemporary philosopher willing to embrace revenge within a justification of punishment is David Hershenov. Noting that 'since people do have vindictive feelings, it is prudent to channel them in a productive, civilized way', Hershenov connects revenge to a restitutive rather than a retributive defence of punishment.

The debt the criminal owes his victim can be paid when the latter takes his legal revenge upon the former. The vindictive pleasures accompanying legal punishment can either increase the value of any other form of payment

31 J. F. Stephen, A History of the Criminal Law in England (1883), quoted in J. Feinberg and H. Gross, Philosophy of Law (Encino, Calif., 1975), p. 544.

32 R. Scruton, The Meaning of Conservatism (Harmondsworth, 1980), pp. 81-3.

33 E. Durkheim, The Division of Labour in Society, trans. W. D. Halls (London, 1984), pp. 44-52. D. Garland, Punishment and Modern Society (Oxford 1980) gives an excellent critique of Durkheim and analysis of debates about the emotional motivation of punishment. 
received, or, where the criminal is destitute, can actually take the place of receiving financial compensation.

Hershenov remarks that the general public as well as the victim want to see a criminal's comfort level reduced, in order that he or she should not seem to prosper from wrongdoing, and that such affliction also provides the criminal with a method of atonement, and the opportunity to be forgiven and to start again with a clean slate. ${ }^{34}$

In contrast to Hershenov, most recent writers on punishment take it for granted that revenge, whether privately or collectively exacted, is morally unjustifiable per se, and that justifications of punishment must make a point of distinguishing it from revenge. ${ }^{35}$ Nevertheless, a suspicion of its presence hangs over some recent developments in criminal justice doctrines. One example is the introduction of 'victim impact statements' in some jurisdictions. ${ }^{36}$ A rather different example, related more directly to private revenge, is the continuing debate on both sides of the Atlantic over the scope of the provocation defence against a charge of murder. ${ }^{37}$ In English law, for example, this defence has for some decades been limited by the requirement that the killer shall have experienced a sudden loss of self-control in

34 D. B. Hershenov, 'Restitution and Revenge', The Journal of Philosophy 96 (1999), pp. 79-94.

${ }_{35}$ Examples are T. Honderich, Punishment (Harmondsworth, 1971), pp. 15, 42-3; and N. Lacey, State Punishment (London, 1988), pp. 26, 57, 184 (but cf. pp. 34-5, where punishment to satisfy victim grievances and forestall private acts of vengeance is justified, though mainly in the context of sustaining public confidence in the law).

${ }_{36}$ For a defence of the use of victim impact statements (VIS), see E. Erez, 'Who's Afraid of the Big Bad Victim? Victim Impact Statements as Victim Empowerment and Enhancement of Justice', Criminal Law Review (1999), pp. 545-56. My suggestion that their use may countenance vengeance is controversial: VIS can be defended as merely providing evidence to enhance the factual basis of sentencing, much as medical evidence of injury would do, though A. Ashworth, 'Victim Impact Statements and Sentencing', Criminal Law Review (1993), pp. 498-509, objects that their use may encourage sentencing in the light of actual rather than foreseeable harm. Ashworth and Erez agree that VIS imply a move to 'a restitutive model of criminal justice' (Ashworth, p. 505; cf. Erez, p. 547) as contrasted with one in which sentencing is determined primarily by considerations of the public interest rather than the interests or wishes of the victim. Erez notes a report on a pilot VIS project in which victim respondents cited as their reasons for providing input 'expressive' reasons (e.g. to let the judge or defendant know what they had suffered) in $60 \%$ of cases, and 'instrumental' reasons (e.g. to affect the sentence) in 55\% of cases (Erez, p. 551, citing C. Hoyle, E. Cape, R. Morgan and A. Saunders, 'Evaluation of the One Stop Shop and Victim Statement Pilot Projects: A Report for the Home Office Research and Development Directorate', 1998).

37 See, for example, in addition to citations in n. 39, V. Nourse, 'Passion's Progress: Modern Law Reform and the Provocation Defense', Yale Law Journal 106 (1997), pp. 1331-1448; Victorian Law Reform Commission, Defences to Homicide: Final Report (2004) (www.lawreform.vic.gov.au). 
response to immediate provocation. ${ }^{38}$ Cases in which violently abused women have carried out premeditated killings of their assailants while the latter have been off guard, or even asleep, have prompted suggestions that, in addition to instances of sudden loss of control, the defence should embrace those 'slowburn' cases in which a killer has undergone accumulated provocation over a long period of time, so that even a sustained and deliberate intention to kill can be taken to be activated by increments of provocation. An obvious problem is that this looks dangerously close to a defence of justified revenge, though sympathizers with this position are, again, generally careful to head off this interpretation. ${ }^{39}$ Jeremy Horder draws on the Aristotelian commendation of proportionate anger in distinguishing three types of motivation for retaliatory killing: loss of self-control; 'anger as outrage' (a phenomenon previously recognized by the law for purposes of mitigation but now discountenanced); and revenge. For Horder, 'someone who acts in outrage acts on a principle of retributive justice', and he suggests amending the Homicide Act of 1957 to substitute references to 'provoked angry retaliation' for references to 'provoked loss of self-control'. In contrast, women who kill 'out of a desire to be revenged which was acted on as such and not in anger [my italics] should have no defense to murder no matter how much sympathy we may feel for them. No civilized society provides mitigation for revenge killings. ${ }^{40}$ On this view, to qualify as revenge the retaliatory act must be cold-blooded, or at least coolly premeditated; retaliation through 'anger as outrage' is hot-blooded, but nevertheless guided by a principle of justice, a 'judgement of wrongdoing'. ${ }^{41}$ Horder cites a case in which a man whose neighbour had repeatedly caused his flat to be flooded rushed upstairs and beat the neighbour to death with a chair-leg. During the beating, the neighbour said 'I'm bleeding - now

38 The Court of Appeal in a 'battered woman' case ruled that instances of 'delayed reaction' to provocation were not excluded from the defence provided that sudden loss of control precipitated the killing itself (R. v. Ahluwahlia [1992] 4 All ER 889).

39 The judicial texts, by contrast, are conspicuously alert to it. For example, the direction to the jury by Devlin J in R. v. Duffy ([1949] 1 All ER 932, CCA), best known for its canonical statement of the doctrine of sudden loss of self-control, is at least as concerned to guard the jury against confusing the acceptance of a provocation defence with the countenancing of justified revenge. See also the remarks of Lord Taylor CJ in R. v. Ahluwalia: 'There are important considerations of public policy which would be involved should provocation be redefined so as possibly to blur the distinction between sudden loss of self-control and deliberate retribution' (R. v. Ahluwahlia [1992] 4 All ER 896). Finally, the 2004 Law Commission report Partial Defences to Murder (http://www.lawcom.gov.uk/docs/lc290(2).pdf), while proposing the abandonment of the sudden loss of self-control requirement, recommends an express exclusion of cases of 'considered revenge' from a reformed provocation defence.

40 J. Horder, Provocation and Responsibility (Oxford, 1992), pp. 190-1.

${ }^{41}$ Horder, Provocation and Responsibility, p. 65. 
are you satisfied?', to which the killer replied, 'No, you're going to die'. On Horder's definitions, this is an instance neither of loss of control nor of revenge, but of 'anger as outrage': the killer's words to his victim preclude loss of control because they indicate 'a judgement of appropriate response', while his fury precludes revenge. ${ }^{42}$

Among the general public, setting aside practitioners of vendetta, the assertion or assumption that revenge is to be shunned is almost as widespread as among philosophers and lawyers, but debates about crime often hint at the legitimacy of revenge. In particular, commonsense defenders of capital punishment for murder typically advance two arguments. The first is an appeal to emotion and runs: (1) 'How would you feel if your child/parent/spouse was murdered - wouldn't you want to kill their killer?' You are supposed to conclude that the state should gratify this wish attributed to the victim's relatives. The second is an appeal to a notion of justice and runs: (2) 'The killer has taken someone else's life, so his own life is forfeit.' You are supposed to conclude from this that the state should take the life that is 'forfeit'. Taken together, these arguments seem to sketch a concept of just revenge, with the state called upon to act as proxy for the injured citizen.

Common-sense opponents of capital punishment tend to reject these arguments as reducing justice (an indisputably good thing) to revenge (an indisputably bad thing). They may add, in reply to (1), that the victim's survivor, who has a special relation to the crime, is just the person whose feelings should not be decisive if the impartiality of justice is to be preserved; and in reply to (2), that justice properly understood does not require the state to 'descend to the same level' as the criminal. The lex talionis may be cited as an example of a pre-civilized conception of justice which we have moved beyond. As the debate becomes more abusive, the abolitionists claim that supporters of the death penalty are actuated by sadism or insensitivity to the suffering of the condemned criminal. The latter respond that the emotional pathology lies elsewhere, that opponents of capital punishment are incapacitated in their judgement because they have failed to imagine adequately the dreadfulness of murder. Certainly, when a civilized person is forced to confront a terrible crime, the shift to vengefulness, at least of language, can sometimes be quite startling. After the deliberate shelling of civilian areas of Srebrenica during the 1990s war in Bosnia, Larry Hollingsworth, a United Nations 'humanitarian' observer, clearly upset but speaking with eloquent deliberation to the international press corps, said,

${ }^{42}$ Horder, Provocation and Responsibility, pp. 66-7. The case is R. v. Devlin [1988]. 
My first thought was for the commander who gave the order to attack. I hope he burns in the hottest corner of hell. My second thought was for the soldiers who loaded the breeches and fired the guns. I hope their sleep is forever punctuated by the screams of the children. ${ }^{43}$

However, the relevance to legal punishment of such responses is not as clear as it may seem. In a powerful defence of retributive punishment, Michael Moore reports a number of atrocious crimes and suggests that most people react to them 'with an intuitive judgement that punishment (at least of some kind and to some degree) is warranted'. ${ }^{44}$ The problem with this claim is the linking of the intuitive reaction specifically with punishment, as distinct from retaliatory harm in general. My own immediate intuitive reaction to the case of the man who raped and murdered a woman and drowned her three small children is not 'some kind of punishment is warranted', but a desire that he be obliterated from the universe, coupled with a complete indifference as to whether this is done with or without due process of law. We may feel at such moments that we would do the obliterating ourselves. When, on the other hand, the possibility of a legal process comes to mind, the intuitional landscape changes, and it is far from clear that the non-retributive thoughts about punishment which then arise (such as the desirability of deterrence, or reform, or incapacitation of the psychopath) are just, as Moore claims, 'bad reasons for what we believe on instinct anyway'. ${ }^{45}$

\section{III}

What conclusions can we draw from this brief survey of philosophical and popular treatments of revenge and retribution? In the first place, there is enough evidence here to show that the intermittent borrowing of 'the language of private revenge' in discussions of punishment is neither merely metaphorical on the one hand, nor sufficiently systematic and consistent to foreclose further investigation on the other. The relations, in purpose, motive and justification, between revenge and punishment are still unresolved; this is most apparent in the widely varying attempts to restrict the scope of revenge so as to distinguish it from (or in a few cases, assimilate it to) punishment by the state.

4313 April 1993, as quoted in The Observer, London, 8 December 1996 (J. Sweeney, review of J. W. Honig and N. Both, Srebrenica: Record of a War Crime (Harmondsworth, 1996)).

${ }_{44}$ M. S. Moore, 'The Moral Worth of Retribution', Responsibility, Character and the Emotions, ed. F. Schoeman (Cambridge, 1987), p. 184.

${ }_{45}$ Moore, 'The Moral Worth of Retribution', p. 184. The phrase is, of course, borrowed from F. H. Bradley (Preface to Appearance and Reality, 1893). 
An even more fundamental question which is unresolved, and indeed generally ignored, in the arguments we have considered is this: Can private revenge (that is an act of revenge carried out without any legal authority whatsoever) ever be justified? And this question can be interpreted in two versions: Can private revenge ever be just? And: Can private revenge ever be morally right?

The latter version might seem to have found an answer. The one approach to unanimity in the existing literature comes in the view, often implied rather than asserted, that acts of private revenge by individuals cannot themselves be morally justified, notwithstanding the conviction of some writers that legal punishment can, or should, give expression to the very feelings that would otherwise motivate private revenge. Even Bentham, who cannot offer any intrinsic objection to the pursuit of vindictive pleasure, implies that the balance of utility is against private revenge (except from the point of view of the revenger). Even Fitzjames Stephen and Scruton, who believe that punishment is properly understood as vengeance, partly justify it as discouraging private acts of revenge. Even Horder, who allows 'anger as outrage' an excusatory role for certain violent offenders, distinguishes this from what he calls revenge, which he insists cannot be excused. Even Moore, who appeals to 'what we believe on instinct', finds that what we believe is that punishment, rather than direct retaliation by individuals, is justified. Even Larry Hollingsworth wanted the affliction of those who bombed Srebenica to be carried out by God or their own consciences, not by some personal revenger. Of the writers discussed, only Aristotle could be construed as possibly allowing that it might be right personally to retaliate, proportionately, against someone who had unjustifiably injured us.

Why is private revenge so generally agreed to be wrong? Let us set aside various defective versions of revenge, such as disproportionate or misdirected revenge, and focus on an example of just, proportionate and well-directed revenge. Dave, for no good reason, punches me hard in the face. I, in response, punch him equally hard in the face. Why is this wrong? Dave has no grounds for complaint, since he cannot, in order to ground any complaint against me, consistently appeal to a law, or a social rule of mutual forbearance, which he has himself broken in his conduct to myself. From his point of view (that is: the point of view which it is reasonable for him to take), my proportionate retaliation is not unjust, therefore in at least a minimal sense it is just. ${ }^{46}$ (In contrast: if I retaliate by punching Dave's well-behaved brother, my revenge will

\footnotetext{
46 Wallace concedes that in certain cases it may be asked: 'On what ground can the revengee complain?... Revenge... need not always involve injustice to the revengee' (Wallace, 'Wild Justice', p. 374).
} 
be both misdirected and, in relation to the brother, unjust.) Moreover, by punching Dave back I have, following Hershenov and others, achieved a vindictive pleasure and at the same time lowered Dave's comfort level, thus repairing the unjust inequality between us introduced by his original act. I have also given expression to my disapproval of his act, and provided him with an immediate opportunity of atonement through acceptance of my retaliation. I am now ready to forgive him and allow him to resume our relations with a clean slate.

There are two possible reasons why this kind of private act of revenge is morally wrong. Either it is intrinsically wrong for anyone to afflict a wrongdoer in retaliation for his wrongdoing; or it is wrong not intrinsically, but because it is I, the private individual who suffered the original wrong, who am afflicting the wrongdoer, whereas others might perhaps be right to do so.

If it is intrinsically wrong, it is not because my act is unjust - unless we stipulate that any unlawful act is unjust precisely in virtue of being unlawful, in which case we have moved to the second type of reason, the type concerned with the locus of the authority to afflict. We expect to return good for good and evil for evil, as Aristotle says, and my proportionate retaliation against Dave seems a just return of evil for evil. No, if punching Dave is intrinsically morally wrong it is because, irrespective of what is just in this Aristotelian sense, it is prima facie wrong to afflict a fellow human being, and even more wrong if the purpose of doing so is to serve my own satisfaction. An Aristotelian ethics which takes as its ideal the happy and successful individual life may allow a person to retaliate proportionately, rather than undergo the humiliation of being a loser. In contrast, an altruistic morality in the Christian tradition, which requires the agent normally to place the other's welfare before his own, will not allow it, since by hurting Dave in order to feel better myself I am placing my welfare before his, thus reversing the priority demanded by altruism. Utilitarian morality requires in this situation either a direct search for the most felicific outcome (assigning equal weight to the good or happiness of all persons affected) or the application of a rule of proven felicific tendency. Taking these altruistic and utilitarian options together, a fairly standard postAristotelian moral view will be that, in order to justify punching Dave, an act which will cause affliction to someone who could otherwise have been left unafflicted, I will need to demonstrate some greater compensating good for others, or a significantly greater compensating good for myself. I could punch Dave to deter him or incapacitate him from further serious acts of violence, for example.

But if afflicting another in personal retaliation, merely because it is just and without any appeal to an overriding good, is morally wrong for these reasons, then punishment by the state, merely because it 
is just and without any appeal to an overriding good, is also wrong for much the same moral reasons. The only difference is that, unlike my retaliatory punch, state punishment is not carried out to give satisfaction to the afflictors, the public authorities (unless these are construed as acting as proxies for the injured citizen), so the reversal of altruism is not so complete. Nevertheless, the affliction of Dave by the state leads, in itself, only to additional suffering for someone. If the law, then, subjects Dave to hard treatment because of his violence towards others, it also requires, just as I do, the justification of some greater compensating good. Here we have, in broad terms, the position of utilitarian, or consequentialist, theorists of punishment.

The second explanation for the wrongness of just and proportionate private revenge holds that afflicting the offender, if the affliction is just and proportionate, may be intrinsically right, but only if this affliction is carried out by those specially authorized by society to do so. The proposition that it may in itself be right will normally be justified in one of two ways. On a consequentialist view (and some versions of retributivist or 'mixed' theories), hard treatment of an offender will be right because, and to the extent that, it yields certain valuable results which outweigh the cost of the affliction of the person punished. It may reform the offender, deter future wrongdoing, give vindictive pleasure to the original victim, manifest society's disapproval of crime, reinforce respect for the law, and so on. Prominent among these compensating goods is that of maintaining due judicial process, rather than leaving retribution to the initiative of the person originally wronged. Through the neutrality and objectivity of law, both offender and victim may be brought to accept 'closure', whereas direct retaliation by the victim risks further counter-retaliation. This danger of returning to the 'war of each against each' is generally accepted as the knock-down reason for restricting the right of retaliation to the public authorities. A further consequence of the criterion of maximizing compensating goods is that the form of retribution may be varied in quite sophisticated ways, with a view to securing such good outcomes as repentance, reform, reconciliation, and so on. A punch in the face is less likely to secure these ends than, say, a suspended sentence of 28 days. It does not matter that there is not a precise match between offence and retaliation.

On some retributive theories, however, such as Moore's, the reason that affliction of the offender may be right is simply that it is just, irrespective of consequences. It is not merely just in the minimal sense that the offender has no grounds for complaint, it is just in the emphatic sense that the offender intrinsically deserves to be punished, and the imposition of punishment is therefore someone's duty. This distinction between the minimal and the emphatic senses of 'just' in discussing retaliation is important. In the minimal sense, the fact that 
a retaliatory act is just does not entail that it is morally right to carry it out: it merely entails that the person who is the object of any retaliation cannot consistently complain about it. This kind of justness has only a contingent significance for morality, where morality is understood as a matter of what I, or we, ought to do. In the emphatic sense, on the other hand, to say that the retaliation would be just is precisely to say that we are morally obliged to carry it out. In the minimal sense, an act may be just (retributively just) but wrong. In the emphatic sense, a just (retributively just) act is necessarily right.

Retributivist theorists who uphold this emphatic, Kantian version are obliged to explain why the right to afflict an offender should be restricted to the public authorities acting through due process of law, and not permitted to the originally injured individual as a private act of revenge. One option for them is, of course, to accept the various consequentialist reasons set out above. But this option may seem inadequate to an especially pure retributivist, in that it is not derived from retributive justice itself. Is there something in retributive justice itself that can motivate an objection to private revenge?

Many philosophers have asserted that private revenge, in practice, tends to excess. However, this does not explain why revenge should be disallowed where it is not excessive, where the revenger merely returns proportionate evil for evil, or lowers the offender's comfort level to much the same extent as the state would do in the form of punishment. Of course a society in which individuals are encouraged to attempt this is a nightmare, but this is a consequentialist argument, not one derived from justice.

One philosopher who tries to confront this issue is Horder. Here is what he says.

Even if we accept that a desire for revenge can give moral reasons for action, those moral reasons are trumped by the fact that in modern societies it is the state that claims an all-embracing authority to act on these sorts of moral reasons, moral reasons relating to the justification for the deliberate infliction of considered punishment and retribution. Ethically well-disposed agents regard themselves as having surrendered their moral right to act for these sorts of reasons. The only limited exception is where a temporary urgency and peculiar importance is given to those reasons by the experience of outrage, when an excuse based on a compassion for the display of an emotion of assumed moral value is ethically acceptable. (175-6)

At the end here Horder is, as usual, careful to stipulate that the experience of 'anger as outrage' is what distinguishes from just revenge the morally motivated retaliation that, in his view, may exceptionally be excused. But the preceding sentences offer no reason, grounded in retributive justice, for disallowing private action. We are simply told that that is how it is in modern societies, and that if we are 
to be ethically well-disposed we must accept it. If there are good reasons for this conclusion, we must assume they are the commonsense consequentialist ones which appeal to the view that we are all better off if the state retains its monopoly on afflicting wrongdoers. A different historical argument is advanced by Green, who tells us that 'private vengeance belongs to the state of things in which rights are not as yet actualized.... In proportion as they are actualized, the exercise of private vengeance must cease. ${ }^{47}$ Since, on Green's account, rights are logically confined to the public realm, it cannot even be claimed that we have yielded up to the state our 'moral right' to retaliate. Rather, it seems that private vengeance 'must cease' because the human condition in a world of rights is so far superior to the historically anterior condition that interpersonal transactions present in the latter and not in conformity to the sovereignty of rights must be disallowed. This again, then, is a consequentialist justification. Hegel's argument against private revenge in Philosophy of Right has a similar structure. The work of discrediting revenge in the reader's mind is done by the usual consequentialist considerations - its alleged tendencies to 'go too far', and to generate further retaliation 'from one generation to another', ${ }^{48}$ But, just as for Green a private person cannot have a right to retaliate - unless, improbably, it is granted to her by the law since rights logically belong to the public realm, so for Hegel the idea of an individual person choosing to bypass the state in taking private revenge is disallowed in advance by the proposition that revenge is the action of a 'subjective will', whereas the will of a tribunal of magistrates is (ideally conceived, at least) 'the universal will of the law' ${ }^{49}$ Both responses miss the point - the point that what the private revenger is doing is deciding not to act within the public realm of rights but to follow her own judgement, not to conform to the (supposed) universal will but to her subjective will. The fact that this is a bad thing for her to do does not show that her act may not in itself be just, unless (begging the question) 'just' is already defined in such a way that no retaliatory act outside an authorized system of criminal justice can be just.

\section{IV}

I have been implying from the beginning of this article that it is desirable to develop a better-focused philosophical account of revenge. Why is this worth doing? One answer can be given from the point of

47 Green, 'Principles of Political Obligation', p. 487.

48 Hegel, Philosophy of Right, s. 102, addition 65: pp. 73, 247.

${ }^{49}$ Hegel, Philosophy of Right, s. 102, addition 65: p. 247. 
view of the potential benefit to public debate. Despite the intellectual headway made by the more hard-headed versions of retributivism in the last few decades, it is probably still true that most educated people reject the view of punishment which can be summed up by saying that criminals are bad people whom we should cause to suffer. A vengeful attitude to criminals is still supposed in such circles to be the preserve of the unreflective and unenlightened. It ought, I believe, to be possible for the case against a vengeful conception of punishment to be stated in a way which avoids premature disrespect towards its adherents, and engages sympathetically with their reasons and indeed their emotions. To achieve this we need to consider what can be said in defence of (just) revenge, and of the thoughts and feelings which might motivate it, and to set out very carefully a vision of morality, politics and law which allows it its due place and no more.

The second answer has an independent importance, but is also connected to the first. Reflection on revenge brings to the surface a number of larger philosophical questions, which are of intrinsic interest as well as strategically relevant to the continuing debate on punishment. I will mention four of these. Some of them have been hinted at already. None of them are unfamiliar, indeed they are versions of certain standard questions in moral and political philosophy, but reflection on revenge may provide a new angle of approach to them.

First, the basis for moral judgements about revenge needs to be explained. Most people, if asked directly for a moral judgement, will unhesitatingly condemn revenge, but some (including some of those who condemn) will admit to a degree of sympathy for the revenger in certain cases. Where a kind of action is unhesitatingly regarded as immoral, considering it may tell us something about the nature of moral value. Where there is, at the same time, a degree of ambivalence in our intuitions, confronting and explaining that ambivalence may help to illuminate further the scope and limits of morality.

Second, the revenger often claims that her act, which may be illegal and/or immoral, is 'just'. Such a claim, unless (which is implausible) it is at once dismissed as nonsensical, calls into question the nature and extent of the association between morality and justice. We need to consider whether an act may be just, in some sense, and yet morally wrong. The possibility of a degree of divergence between the just and the morally right opens up the further question of the nature and function of law, which is generally assumed to have a foundation at once in morality and in justice.

Third, instances of injury-and-revenge represent a bad kind of reciprocity, in contrast to the good kinds of reciprocity which are generally taken (in social contract theories, theories of 'moral community', etc.) to be necessary both as a basis for social order 
and as a background to justifications for punishing an offender. The revenger both engages in reciprocity (you harmed me, so I will harm you) and at the same time, at least in many cases, appeals for justification to the fact that the original offender has repudiated some previously operative reciprocal principle, such as mutual forbearance, non-violence or respect for property, or simply mutual obedience to the law. Reflecting on revenge and its claims to be just may help us to understand more clearly the way perceptions of, and commitments to, reciprocity operate in our collective political life.

Finally, where any person who has done wrong is afflicted, whether by revenge or legal punishment, the question arises whether such affliction may be 'deserved' at the deepest level of human responsibility; and if so, whether the fact that it is or is not so 'deserved' affects the justification of its imposition by a particular person or persons. Some believe that this question of desert for punishment has for all practical purposes been long settled, and that determinist qualms about holding even mentally competent people responsible for their actions must yield to our common and mutually respectful conception of other citizens as free agents. ${ }^{50}$ But since this view is dependent on certain assumptions about the reciprocal beliefs and attitudes necessary for a well-ordered society, it too may benefit from being revisited. ${ }^{51}$

bjrosebury@uclan.ac.uk

${ }^{50}$ See P. F. Strawson, 'Freedom and Resentment', Free Will, ed. G. Watson (Oxford, 1982).

${ }^{51}$ I am grateful to Terry Hopton, and to a number of anonymous referees, for invaluable advice, criticism and encouragement. 
Copyright of Utilitas is the property of Cambridge University Press / UK and its content may not be copied or emailed to multiple sites or posted to a listserv without the copyright holder's express written permission. However, users may print, download, or email articles for individual use. 